\title{
CHARACTER EDUCATION VALUES FOUND IN KHALED HOSSEINIS’ A THOUSAND SPLENDID SUNS
}

\author{
I Dewa Gede Arisudana, Deane J Wowor, Mister Gidion Maru
}

\begin{abstract}
This research intends to identify the character education value that contained in the novel "A Thousand Splendid Suns". This research used qualitative descriptive method. The sources of data were taken from the novel A Thousand Splendid Sunby Khaled Hosseni and other documents as journals, book, or articles related to the research. From the analysis of the novel A Thousand Splendid Sunthere is religious value depicted form the figure of Mullah Faizullah through his attitude in reminding Mariam to believe in God's Plan under any circumstances, because the Koran always speak the truth. Followed by the nationalism value was illustrated from a teacher figure named Shanzai which told the students that the unity of a nation is a priority in maintaining peace of a country. Then followed by the value of integrity depicted by the village leader named Habib Khan that shows responsibilities of a good leader will not put his or her personal interests first. Followed by the independent value seen in Tariq struggle in continuing his life despite his imperfect conditions, Tariq remains self-sustaining and does not depend on others. And followed by the value of mutual cooperation depicted from the figure Fariba through her polite and friendly attitude with the people she met. It can be concluded that the novel "A Thousand Splendid Suns " reflect all of the values of character education.
\end{abstract}

Keywords: Character Education, Novel, Values.

\section{INTRODUCTION}

Character Education is an attempt that conducted to revise the moral value of a person to have its own characteristics in reflecting their personality as a member in a certain circle, according to some expert "Character education is a growing discipline with the deliberate attempt to optimize students' ethical behavior" (Berkowitz \& Hoppe, 2009; Katilmis, Eksi, \& Öztürk, 2011). The U.S. Department of education stated that "an explicit learning process from which students in a school community understand, accept, and act on ethical values such as respect for others, justice, civic virtue and citizenship, and responsibility for self and other" (U.S. Department of Education, 2006). 
Character education plays an important role in improving the moral value of a person, especially students as the next generation of a Nation. According to Maru, "the educational process is not merely aimed at shaping the intellectual achievements but also establishing the spiritual ones, teaching and learning activity comprise with the steps to meet learners' needs which are adapted into a certain standard of a graduate profile (Maru, 2014, pp.1-2). In the current globalization era the entry of foreign culture in Indonesia gives a great impact in the characters development, the young generation tend to be more affected by the incoming lifestyle of foreign cultures as an example, the increased of social promiscuity, changes in how to dress, and the increased of violence against teenager that happened recently.

In forming the characters there are several facilities and infrastructure used, Brown revealed that "instructional media are utilized in learning activities will affect the effectiveness of learning" (Brown, 1973). A literary work such as novels, short stories, and poetry can be used as a means of study because it is full of meaning and value of life. Novel is one of the most popular literary works, the story in a novel is not only tells about a love story or fiction, it is contain various things related to life so that the contents of the novel can be used as a instructional media because it contains historical value, life experience, and also the value on certain characters.

Related to the value of characters, there are 5 main character values based on Presidential regulation number 87 of 2017 on strengthening character education, there are "1. Religious, 2. Nationalism, 3. Integrity, 4. Independent, 5. Mutual cooperation" (Kemdikbud, 2017).

The role of character education is to shape students personality in order to increase the students competence over it. Teachers were expected to facilitate the students in building their characters based on the current curriculum and hopefully in the future the students will have a good quality as the next generation. A literary works can be a means of building the students character for example a novel because it is portraying life, the purpose of this research was to identify the values of character education in the novel A Thousand Splendid Suns.

\section{REVIEW OF LITERATURE}

Hişmanoğlu in 2005 stated that "In recent years, the role of literature as a basic component and source of authentic texts of the language curriculum rather than an ultimate aim of English instruction has been gaining momentum. Among language educators, there has been a hot debate as to how, when, where, and why literature should be incorporated in ESL / EFL curriculum. Vigorous discussion of how literature and ESL / EFL instruction can work together and interact for the benefit of students and teachers has lead to the 


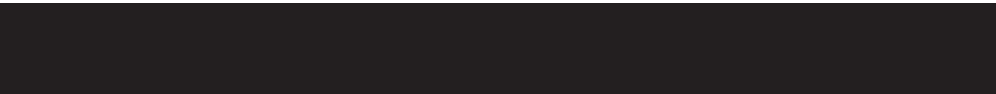

flourishment of interesting ideas, learning, and improved instruction for all" (Hişmanoğlu, 2005, p.1). Related to the theory, Liando in 2012 stated that learners, when they possess positive attitudes toward the target language and willingness to integrate themselves within the culture of that group and become a part of that society, are attributed as having integrative motivation (Liando, 2012, p.2). There are four reasons teacher need to use literature in the classroom ; 1. Valuable Authentic Material, 2. Cultural Enrichment, 3. Language Enrichment, 4. Personal Involvement (Collie and Slater,1990, p.3, Maru, 2009, p. 4).

Based on Presidential regulation number 87 of 2017 on strengthening character education, there are 5 main character value :

1. Religious

Religious value reflects the belief in God Almighty embodied in the conduct of practicing religious teachings and beliefs, respecting religious differences, upholding tolerant attitude towards the implementation of religious worship and other beliefs, living harmonious and peaceful with the believer of other religions. Implementation of the religious character is shown in the attitude of love of peace, tolerance, respect for different religions and beliefs, firm stance, confidence, cooperation between religion and believer, anti-harassment and violence, friendship, sincerity, not impose will, love environment, small and marginalized (Kemdikbud, 2017). Related to the theory Émile Durkheim stated that religion is an integrated system consisting of beliefs and practices related to the sacred, a religious people try to continue to improve their faith through the routine of worship, achieving the perfect spiritual holiness (Durkheim, 1965).

\section{Nationalism}

Nationalism value is a way of thinking, acting, and doing that shows loyalty, awareness, and high appreciation for the language, the physical, social, cultural, economic, and political environments of the nation, placing the interests of the nation and the country above the interests of the self and the group. The reflection of Nationalism character is shown through the attitude of the nation's own cultural appreciation, safeguarding the nation's cultural richness, willing to sacrifice, excel, and achievement, love the country, protect the environment, obey the law, discipline, respect the diversity of culture, tribe, and religion (Kemdikbud, 2017). Esti Ismawati in 2018 stated that Nationalism is a group of individuals who want to unite with other individuals with the impulse of the will and the psychical need, it is the highest allegiance that individuals give to nation and state, the unity of feelings and temperament arising from the similarities of fate, as the result of political, economic, social, and intellectual factors at a certain level in history (Ismawati,2018).

3. Integrity

Integrity value is the underlying value of behavior based on an attempt to establish itself as a person who is always trustworthy in words, actions and work, committed and 
faithful to humanitarian and moral values. The character of integrity includes the attitude of responsibility as a citizen, actively involved in social life, through the consistency of actions and words based on truth. A person of integrity also values the dignity of the individual (especially persons with disabilities), and is able to demonstrate exemplary (Kemdikbid, 2017). According to Henry Cloud integrity is an effort to become a complete and integrated person in every part of the different self, which works well and performs its function in accordance with what has been designed previously, it is closely related to the wholeness and effectiveness of a person as a human being (Cloud, 2006).

\section{Independent}

Independent value is an attitude and behavior of an independent person that not depend on others and uses all the energy, mind, and time to realize their hopes, dreams and ideals. Independent students have a good work ethic, tough, capable of fighting, professional, creative, courage, and become lifelong learners (kemdikbud, 2016). In 1985 Kartini Kartono stated that the independence of a person is seen when the person is facing a problem and how they solved it on with thier own power without seeking help from parents and they will be responsible for any decisions taken through various considerations, then this indicates that the person is able to be independent (Kartono, 1985).

\section{Mutual cooperation}

Mutual cooperation reflect acts of respect for the spirit of cooperation and shoulder to shoulder to solve common problems, establish communication and friendship, provide assistance / help to people in need. It is expected that students can show respect for others, be able to work together, inclusive, able to commit to joint decisions, consensus consensus, help, empathy and solidarity, anti discrimination, non violence, and volunteerism (Kemdikbud, 2017).

\section{RESEARCH METHODS}

This research used qualitative method. The data were the form of literature review of a literary work. Clissett stated that "qualitative research covers a wide range of approaches for the exploration of "human experience, perceptions, motivations and behaviors" and is concerned with the collection and analysis of words whether in the form of speech or writing" (Clissett 2008, 100). On the statement above, qualitative method is most suitable method to be used in analyzing novel. This research formulated in a descriptive form. The source of data taken from novel A Thousand Splendid Suns by Khaled Hosseni. The data divided into two kinds of sources: primary source and secondary source. The primary source will be the novel A Thousand Splendid Suns by Khaled Hosseini. The secondary sources will be the data or documents that took from many source as journals, book, or articles that related 
to the research . In analyzing the data, the writer used Jeremiad approach which is so-called T-Ex Approach. According to Maru(Maru, 2014, pp.5-6, Maru, 2018, pp 2) . The T-Ex Approach, a text-based approach, suggests three phases that have to be included in learning activities namely text explanation, text examination, and text expectation such as;

Text explanation is the first phase perceives a text as something comes from the present condition. It can portray the reality of moment of the text production.

$>$ Text examination is the second phase urges the deep examination of the text which is carried out by connecting the context with knowledge such as multidisciplinary references, history, past figures, location, and Holy Book verses. These are intended to gain encouragement and solution for the current condition.

$>$ Text expectation is the last stage is marked by the finding of moral values out of the text. The value discovery is crucial at this moment of interpretation since it is capitalized to suggest the enactment of a certain expected attitude

This approach used in analyzing the collected data of the research related to the values of character education contained in the novel.

\section{FINDING AND DISCUSSION}

Values :

1. Religious Values

According to Kementerian Pendidikan dan Kebudayaan, religious value is the value that reflect belief in God Almighty contained the behavior of practicing religious teachings and beliefs, respecting differences between other religions, uphold the tolerant attitude towards the implementation of religious worship and Another belief, live harmoniously and peacefully with the followers of other religions (Kemdikbud, 2017). It refers to the belief in God as well as living in peace and harmony with the followers of other religions seems to be the value expected from education of character, the religious value implied in the novel $\mathrm{A}$ Thousand Splendid Sunby Khaled Hosseini, can be seen in the data below :

they'll comfort you too, Mariam jo,"he said". "you can summon them in your time of need, and they won't fail you. God's words will never betray you, my girl. (Hosseini, 2009, p.17)

In the above quotation it is seen that Mullah Faizullah is encouraging Mariam that her faith is not in vain, God will take care of her, God is always watching for those who put believe in Him. This replies that Mullah Faizullah is recalling Mariam 
spiritual feelings, it is common since Mariam have acknowledge the verses in the Koran. Émile Durkheim stated that religion is an integrated system consisting of beliefs and practices related to the sacred, a religious people try to continue to improve their faith through the routine of worship, achieving the perfect spiritual holiness (Durkheim, 1965). The religious value seen in the above quotation shows the effort of Mullah Faizullah who tried to convince Mariam that verses inside the Koran will always comfort her in any ways. The religious figure of Mullah Faizullah can also be seen in the quotation below :

he sat next to her and cupped her face in his hands. "you go on and cry,

Mariam jo. Go on. there is no shame in it. But remember my girl, what the

koran says, 'blessed is $\mathrm{He}$ in whose hand is the kingdom, and He who has

power over all things, who created death and life that He may try you.' The Koran speaks the truth, my girl. Behind every trial and sorrow that He makes us shoulder, God has a reason.(Hosseini, 2009, p.38)

In the above quotation Mullah Faizullah reminds Mariam that everything happens to her is in the power of God. Here, he was clearly tried to strengthen Mariam to go on living with hope and trust God's planning despite every temptations she is facing, whether it is happiness or sadness, this is contained in the Koran which gives guidance for the believer and leads them to the truth. Therefore, as the most noble creatures of God humans must hand over every plan and effort to Him, the Creator of all things. Although Mariam said that she has finished studying it, yet she got motivated by Mullah to keep reading the verses in the Koran. She saw the seriousness of Mullah Faizullah as well, as the one who always wanted to teach and remind her to stick with her routine reading the verses in Koran, as seen in the following quotation:

he showed her the Koran he had brought with him and opened it. "I figured no sense in skipping our routine, eh?"

“you know I don’t need lessons anymore, Mullah sahib. You taught me every surrah and ayat in the Koran years ago," He smiled, and raised his hands in a gesture of surrender. "I confess, then. I've been found out. But I can think of worse excuse to visit you."

"you don't need excuses. Not you."

"You're kind to say that, Mariam jo."

He passed her his koran. As he'd taught her, she kissed it three times-touching it to her brow between each kiss - and gave it back to him.

(Hosseini, 2009, p.43) 
Mariam greatly appreciates Mullah Faizullah as the one who always look after her and comes to teach her value in the Koran, although Mariam's situation at that time was sad because she just lost her mother. It seems that Mullah Faizullah is keep reminding Mariam of God's words that has everything she needs even when they have finished studying it, however it always able to comfort people that read it. This was the act of directing someone to the positives mindset, this leads someone to have a strong personality. Therefore, people will be able to avoid focusing in the despair situation that they facing right now.

Thus, by recalling the verses in the Koran, believers would always get courage and confident to face the challenges that awaits in the future, and also this can give a power to the believer in handling a situations that may bring them down even giving up. Since, it is important for most people to have a strong base in their life, people need guideline that may lead them to the joyful of life by trusting God's words that may comfort every vulnerable heart. Besides studying, Mullah Faizullah also gave a wisewords to Mariam to not dissolve in grief:

Nay, nay, nay." Mullah Faizullah put his hand on her knee. "Your mother, may Allah forgive her, was a troubled and unhappy woman, Mariam jo. She did a terrible thing to herself. To herself, to you, and also to Allah. He will forgive her, for $\mathrm{He}$ is all-forgiving, but Allah is saddened by what she did. He does not approve of the taking of life, be it another's or one's own, for He says that life is sacred. (Hosseini, 2009, p.43)

In the statement above Mullah Faizullah gave enlightenment to Mariam who at that time blamed herself for thinking that her mother died because of her mistake. This statement clearly suggested Mariam that life is a precious gift of God, she has to cherish the life that God gave to her. He said so because the situation above was actually happened after her mom suicide when she found out Mariam was not in home that time, then she felt so desperate thinking Mariam betrayed her and all of sudden she thought her life was not precious anymore if she lose the loved one. This was also shows the contrast between a believer that lives in the way Koran directed and the believer that do not really live and have less perseverance in their faith to God. In this case Mariam's mother, meanwhile the believer that shows devotion to God with sincerity and strong faith will always have a good things to be focused at and always have a strong mentality in every situation they are facing in life. It refers to Mariam and Mullah Faizullah in living their life with fully depending and trusting God in every steps of their life. 
Here, Mullah Faizullah once again reminds Mariam that her life is precious, and she has to put believe in God despite the sadness she is facing, God never approved of the bad things happened, because He is merciful and caring of His creations. The feeling acceptance of God's plan drives believer to feel grateful for everything that life brings. It also can be seen from the figure of Hakim who is the father of a girl named Laila. Hakim prayed to God for bringing Laila to his life, it can be seen below :

But I'm glad I have you. Every day, I thank God for you. Every single day.

Sometimes, when your mother's having one of her really dark days, I feel like you're all I have, Laila. (Hosseini, 2009, p.148)

The quotation above shows the feeling of a father that thankful to God even after he lost two of his sons in the battlefield. Human commonly feel so depressed or losing their mind when facing such trials. But in this circumstance, the father who is a believer focused on positive things that leads him to choose happiness despite the sadness that occurred in their family that time. It depicts a big difference between the believer and commom people, whereas common people feel the deep lost when facing such trial, but believer always gain something precious to go on living.

The religion values that found in that quotation was about feeling grateful for God grace and gift in the middle of life temptation which then directs human to focus on positive things in life. Besides, another positive value that revealed the strong impact of religion on human life is faith. It can be seen in the following quotation:

Mariam watched the snow falling down, she pictured Mullah Faizullah

twirling his tasbeh beads, leaning in and whispering to her in his soft, tremulous voice, But it is God Who has planted them, Mariam jo. And it is

His will that you tend to them. It's His will, my girl. (Hosseini, 2009, p.250)

Considering the words of Mullah Faizullah made Mariam aware of the reason for the presence of Laila and her daughter Aziza in her life that brought new hope for her even they once have a little clash, as seeing the development of Aziza give happiness to Mariam who has long looked forward to the presence of a child. It makes her closer with Laila and her daughter. Here, she has convinced herself of God's fate by remembering Mullah's words to her about God's plan that she has to deal with always has a purpose and a message for the believer. It also depicts the feeling of acceptance of God's fate and altogether testing the faith of the believer to love one another no matter what. 
Moreover, this quotation distinguished the perspective of the believers and nonbelievers, whereas the believer have the tendency to love each other and to accept everyone around their life as the gift and message from God that bring out purpose for life and drive out hatred towards other, meanwhile non believer tends to have less affection or feeling of caring other people surround their life. That drives Mariam to share more about her belief to people that she accepted and loved in her life, it can be seen from the following quotation when Mariam taught the value that she had learned to Aziza who at that time was 5 years old :

Mariam had started teaching Aziza verses from the Koran. Aziza could already recite by the heart the surrah of ikhlas, the surah of fatiha, and already knew how to perform the four ruqats of morning prayers.

(Hosseini, 2009, p.290)

Mariam's knowledge of the Koran makes Aziza quickly understand every verse in it and able to spell it correctly, it is common because reading the verse of the Koran has become a routine for Mariam. This quotation also shows Mariam's gratitude of having someone to share her knowledge with, as well as inculcate religious values on Aziza early that aims to form a personality that is obedient to the teachings of religion and able to apply it in daily life. it is shows the act of a believer that lives corresponding to the guidance of Koran, this faith makes the believer able to properly practice every value in the Koran. even though the situation of Kabul was in chaos that time because it was taken over by a group called the Taliban. However, Tariq who is the father of Aziza believes that God will lead them under any circumstances:

Allah is good and kind, and Allah provides, and, as long he provides, I

will see to it that Aziza is fed and clothed. That much I promise you.

(Hosseini, 2009, p.311)

The statement above shows Tariq convincing Laila that God will always accompany the good intentions of a person, this is common since Tariq believe that in every effort he made, he surround his plan to the will of God. This also emphasized the strong faith of a believer that God will never forsake nor abandon His creation that He loved, instead He will fulfill all the necessity of His creation. Based on the analysis of each quotation, it is found that circumstances are not a reason for a person to give up, no matter how difficult the situation was, God has a bigger plan for those who made an effort to pass every trial, God will lead them in every move they made. 
2. Nationalism Value

According to Kementerian Pendidikan dan Kebudayaan, Nationalism value is a way of thinking, acting, and doing that shows loyalty, awareness and high appreciation for the language, the physical, social, cultural, economic and political environment of the nation (Kemdikbud, 2017). It means that Nationalism value can be interpreted as the attitude and conscious action in showing love and appreciate to everything that builds the country and be faithful to protect its country, the nationalism value implied in the novel A Thousand Splendid Sunby Khaled Hosseini, can be seen as follows :

That's why our soviets comrades came here in 1979. To lend their neighbor a hand. To help us defeat these brutes who want our country to be a backward, primitive nation. And you must lend your own hand, children. You must report anyone who might know about these rebels. It's your duty. You must listen, then report. Even if it's your parents, your uncles or aunts. Because none of them loves you as much as your country does. Your country comes first, remember! I will be proud of you, and so will your country.

(Hosseini, 2009, p.112)

The above quotation shows the Nationalism Value through a teacher figure named Shanzai who explains to the students the importance of unity among Afghans people to protect their own country from the disruption of the rebels who want to take over, it is also a form of applying the value of nationalism through learning in school, if this application goes well, then a harmonious and peaceful country will be created, the quotation also shows clearly the illustrations of Shanzai's love and loyality to her country. On the other side, the love of country can also be seen from the harmony of every citizen in preserving unity, as in the following quotation:

Babi had wiped his eyeglasses clean with the hem of his shirt. To me, it's nonsense - and very dangerous nonsense at that —all this talk of I'm Tajik and you're Pashtun and he's Hazara and she's Uzbek. We're all Afghans, and that's all that should matter.(Hosseini, 2009, p.128)

The statement above shows how the differences among tribes in Afghanistan existed. in fact this is the wealth of a nation, because all of these tribes are one. but if there is no sense of unity of the diversity, the wealth of a nation may become a threat, if each tribe only focuses on its own interests, a country will be on the verge of collapse, this can be seen from some countries that still beware of differences. For example, the majority and minority. The majority generally prefer the interests of their own group and tend to override even oppress the minorities. This kind 
of attitude may slown down the development process of a country. Therefore, in order to realize a developing and competitive country, a unity of all sectors of the country is required. Besides unity, the nationalism values depicted from the figures Hakim is also illustrated when Hakim takes Laila and Tariq to a historical place, Hakim explains the importance of knowledge of the nation's own history :

I wanted you to experience it. But I also wanted you to see your country's heritage, children, to learn of its rich past. You see, somethings I can teach you. Some you learn from books. But there are things that, well, you just have to see and feel. (Hosseini, 2009, p.147)

The statement above shows Hakim gives an explanation of the remaining historical heritage. It is an inheritance that every citizen should safeguard, like a quote that says a great country is a country that appreciate its history, this quote explains that a country exists because of its history, as its predecessors that fight for and defend their country. Nowdays, in preserving and maintaining country does not have to go through a war, but it can be realized through appreciation and willing to learn from the richness of history that exists. Thus the wealth of the country will always live in its citizens. Beside, the love of a country also reflected in the figures Fariba who is the mother of Laila who at that time insisted not to leave Kabul even though Kabul is in chaos :

And so they would stay. They would stay until the war ended. And they would stay for whatever came after war. (Hosseini, 2009, p.149)

In the quotation above shows Fariba willing to stay in Kabul no matter what happens, because she promised to her fallen sons that they would see the peace in Kabul through her eyes, Although Hakim already persuade her to move into another city, Fariba made them settle in Kabul despite the chaos. A few days later the Kabul was attacked and there was an explosion around the city, the stray rockets destroy every random buildings there. And once the rockets attacked Laila House and killed her parents, only Laila survive from that explosion. While Kabul is in chaos, Tariq takes Laila to a place far away from the Kabul until the chaos end. Years passed by, Laila got a news that the Afghans army had captured Kabul, this made Laila decided to return :

I am happy," Laila says. "Of course I am. But ... where do we go from here, Tariq? How long do we stay? This isn't home. Kabul is, and back there so much happening, a lot of it good. I want to be a part of it all. I want to do something. I want to contribute. Do you understand?.(Hosseini, 2009,p.379) 
The utterance above shows how Laila loved her country, she willing to help and contribute in rebuilding Kabul even though she lived happily far away from Kabul with Tariq, but Laila could not stop herself from returning to Kabul, the place she was born and studied, the place that means so much for Her.

Based on the analysis of each data that found, it can be concluded that the value of nationalism was illustrated in a sense of loyalty to a country which is reflected in the awareness of the importance of preserving and look after the legacy of the ancestor and the attitude of wanting to protect a country from the rebels who willing to destroy.

3. Integrity Value

According to Kementerian Pendidikan dan Kebudayaan, integrity value shows the behavior based on the effort to make itself a trustworthy person in words, actions and work, committed and faithful to humanity and moral values. the value of integrity includes an attitude of actively involved in social life, through the consistency of actions and words based on truth (Kemdikbud, 2017). It refers to the attitude of responsibility that aims to gain the trust of others, The integrity value implied in the novel A Thousand Splendid Sunby Khaled Hosseini, can be seen in the data below :

Mariam and Nana milked the goats, fed the hens, and collected egs. They

made bread together. Nana showed her how to knead dough, how to kindle the tandoor and slap the flattened dough onto its inner walls. Nana taught her to sew too, and cook rice and all the different topings : shalqam stew with turnip, spinach sabzi, cauliflower with ginger. (Hosseini, 2009, p.15)

The quotation above shows Nana who is the mother of Mariam giving a lesson as the responsibilities to do in a house, Nana taught Mariam some important things for her to do it herself. This is an obligation that should generally be understood by every woman, because someday someone must be able to live independently. The above quotation also shows a person's quality can be trusted from his/her attitude that can be seen through the way the person is carrying a responsibility given or entrusted. The sense of responsibility must be taught as earlier as possible so that a person will able to show the character with integrity in the future. People with the integrity character born as a figure who can be a role model and nurture their character that can bring a good influence in the life of society. The figure of the village leader in the place where Mariam lives shows a high value of integrity towards his people, it can be seen in the following quotation :

gul daman's leader, the village arbab, Habib Khan, a small-headed, bearded man with a large belly who came by once a month or so, tailed by a 
servant, who carried a chicken, sometimes a pot of kichiri rice, or a basket of dyed eggs, for Mariam. (Hosseini, 2009, p.15)

The above quotation shows that a good leader will not put his or her personal interests first. That is what Habib Khan figures out, he is the village leader where Mariam lives with her mother. His responsibilities were the evidence as he paid attention to Mariam and her mother who lived in a kolba that was even far from what so called properous. As a leader, he does not just do his duties and responsibilities indoors, but he goes straight down to see and provide help to those who need. It is found that a leader is not only judged by his performance as the head of an institution, but a leader is judged by the welfare of the people under his leadership. Exemplary figure who always be a role model is very needed, because of his presence that motivate people in a group of society. Besides a leader, a Teacher can also be a role model for his students, it can be found in the quotation below :

Mullah Faizullah, the elderly village koran tutor, its akhund. He came by once or twice a week from gul daman to teach mariam the five daily namaz prayers and tutor her in koran recitation, just as he had taught nana when she'd been a little girl. (Hosseini, 2009, p.15-16)

Nowdays, it's very rarely to find someone who has a high degree of integrity, most of people just did their duties based on loyalty for personal gain. But it is different from the situation of Mullah Faizullah, the oldest Koran teacher in gul daman . Twice a week he visits Mariam's house to teach Mariam each verse in the Koran, the journey that Mullah Faizullah takes to go to Mariam's house is also quite far away. However, Mullah Faizullah maintains the trust given to him and his responsible for performing the task of teaching the Koran to his student . In the above quotation also shows that a teacher should contribute to the development of his students and set an example for them because a good teacher is person who dedicates himself for the knowledge he or she has to teach to their students. The attitude of responsibility is also seen from a character named Hakim who is the father of a girl named Laila, as seen in the quotation below :

I know you're still young, but I want you to understand and learn this now, he said. Marriage can wait, education cannot. You're a very, very bright girl. Truly, you are. You can be anything you want, Laila. I know this about you. And I also know that when this war is over, Afghanistan is going to need you as much as its men, maybe even more. Because a society has no chance of success if its women are uneducated, Laila. No chance.

(Hosseini, 2009, p.114) 
In the above quotation shows Hakim sense of concern for Laila's educational qualities that makes him committed to give Laila a proper education, because Hakim knows the potential from his daughter and gives Laila the discretion to learn things. Even though at that time education for a woman is severely restricted. Nevertheless Hakim remains determined to be able to provide education in accordance with Laila's abilities. Beside the figure who is responsible for the education of his daughter, Hakim also a figure of teacher favored by his students. It can be seen in the following quotation:

What a first-rate teacher he was," Mammy said. "His students loved him.

And not only because he wouldn't beat them with rulers, like other teachers did. They respected him, you see, because he respected them. He was marveleous. (Hosseini, 2009, p.119)

In the above quotation shows Fariba who is praising the quality of her husband Hakim while he is still actively teaching. At that time Hakim was the best teacher that his students loved so much. Hakim was dismissed because he supported the communist regime, at that time the communist regime gave women the freedom to get an education and was given the opportunity to choose the desired profession. Hakim has a strong integrity character as a lecturer as well as an educator, he is willing to bet himself to be fired for an education that he thinks is worthy to be earned by everyone. From this explanation, it is found that a character with integrity has responsibility for what is entrusted to him or her and shows the quality of themself and consistent with the decision taken despite having to bear a high risk. The attention given by Hakim made Laila made grown up to be a responsible child. Laila keep and care for her parents, it can be seen in the following quotation :

Laila washed Mammy's dresses and chaged her sheets. She coaxed her out of bed for baths and meals. She was the one who ironed Babi's shirts and folded his pants. Increasingly, she was the cook. (Hosseini, 2009, p.140)

In the above quotation shows Laila doing all the house chore, from cooking to clean, especially at that moment Laila felt depressed from her mother who ignored her presence. This is due to the profound grief that her mother still feels for losing the two sons who were killed while fighting against the soviets army. However, it did not shake Laila's determination to care for her mother and father. From this explanation, it is found that the value of integrity in a person will not disappear even under any circumstances, this is a self-giving in the form of responsibility for the entrusted task. Laila has a strong sense of responsibility for the people around her, she also provides resistance when Rasheed tells her daughter to be a 
street beggar :

There will be others like her, younger even," Rasheed said. "Everyone in kabul is doing the same."

Laila told him she didn't care what other people did with their children.

"I'll keep a close eye on her," Rasheed said, less patiently now. "It's a safe corner. There's a mosque across the street."

"I won't let you turn my daughter into a street beggar!" Laila snapped.

(Hosseini, 2009, p.292)

Laila disagreed with rasheed's understanding about a children being a street beggar was a natural thing for them to do at that time, but rasheed insisted on telling Aziza to be so, Laila who felt disrespect against Rasheed's wish made her forced to slap him, Laila managed to make Rasheed away from her daughter, then Laila decided to bring Aziza to the orphanage because the chaos that still struck Kabul, at the orphanage, Aziza gets good treatment and lessons :

Aziza said Kaka Zaman made it a point to teach them something every day, reading and writing most days, sometimes geography, a bit of history or science, something about plants, animals. (Hosseini, 2009, p.314)

Aziza was a new kid who entered the orphanage that time. Zaman is a guard at the orphanage who keeps and gives lessons to those who live there. The sincerity of Zaman in giving the lessons made Aziza impressed since Zaman did the task that entrusted to him. He taught various things to Aziza and other orphanage children. From this explanation, it is found that the attitudes that shows from Zaman reflect the value of integrity seen through his sincerity in carrying out the entrusted duty.

Based on the analysis of each quotation found, the integrity value seen through attitudes and capabilities that can be calculated through the responsibility and honesty that shows a form of exemplary in order to obtain a better life goals.

4. Independent Value

According to Kementerian Pendidikan dan Kebudayaan, Independent value shows the attitudes and behaviors whose not depends on others and use all of he/ she energy, thought, time to realize their hopes, dreams and goals. Independent person have a good work ethic, tough, willing to fight, professional, creative, courage, and become lifelong learners (Kemdikbud, 2017). It means that independent values shows the confidence attitude through a good work ethic in order to realize expectations and ideals with the energy and mind of a person without expecting the help of others. The Independent value implied in the novel A Thousand Splendid Sunby Khaled Hosseini, can be seen in the data below : 
It was Mullah Faizullah who had taught Mariam to read, who had patiently looked over her shoulder as her lips worked the words soundlessly, her index finger lingering beneath each word, pressing until the nail bed went white, as though she could squeeze the meaning out of the symbols. It was Mullah Faizullah who had held her hand, guided the pencil in it along the rise of each alef, the curve of each beh, the three dots of each seh. (Hosseini, 2009, p.16)

In essence, there is a patience in the good work ethic, as depicted from the figure of Mullah Faizullah in reflecting the independent character, with the responsibility as a Koran teacher, Mullah Faizullah patiently look over Mariam in giving a guidance about how to read and understand each word and symbols inside the Koran, his persistence in giving a lesson reflects the professionalism of an instructor. His effort shows the independent value that exists on his figure.

The work ethics and professionalism of Mullah Faizullah was strongly suggested the reader to give all she/he got to everyone that really need the guidance in this case as a Koran teacher even it means he has to sacrifice time, energy and thought in running his responsibility as the standard demanded on his duty even more than it. Besides, independent character also showed by a figure named Tariq when he had to find a work in a chaos that was caused by the ongoing warfare in Afghanistan:

"One look at my leg and it was over." There were other jobs. Ditches to dig, hovels to build, water to carry, feces to shovel from outhouse. But young men fought over these jobs, and Tariq never stood a chance. Then he met a shopkeeper one day, that fall of 1993. "He offered me money to take a leather coat to Lahore. Not a lot but enough, enough for one or maybe two months' apartement rent." (Hosseini, 2009,pp.327-328)

The quotation above shows the attitude of Tariq that is not depend on others, although with a physical condition that is no longer perfect on one of his legs that was once exposed from a landmines planted by soviet troops, Tariq was forced to use prosthetic limbs, his condition made him difficult to get a job in the midst of the chaos that swept Afghanistan, people were fighting for work so Tariq never got a chance. But it did not make Tariq losing his hope, he kept trying to find a job he could do until one day he met a shopkeeper who offered a job. Despite the imperfect conditions, Tariq remains self-sustaining and does not depend on others to continue his life, the figure of Tariq reflects a strong personality through effort and hard work to achieve his goal.

His persistence was really motivating and inspiring, since he showed the soul of a strong fighter that never lose passion in facing fate of life. His will to survive the 
chaos on the battle field reflected the toughness of a man that do whatever it takes to conquer his self-dependent on others by giving his best efforts in sufficing his life necessity despite his imperfection. A strong personality is not only seen from the figure of Tariq, when the war of chaos has begun to subside, the people who lives in the city of Kabul began to take the initiative to rebuild the city, it can be seen in the following quotation:

Laila finds it strange to be back in Kabul. The city has changed. Every day now she sees people planting saplings, painting old houses, carrying bricks for

new ones. They did gutters and wells. (Hosseini, 2009,p.398)

The action that conducted by people of Kabul after the subsided of the chaos reflected the independency of committing and affording something for the wellbeing of the city. They clearly showed that they did not being dependent fully on governmental aid or volunteers from other country. Instead, they chose to behave independently by hand to hand helping each other in the city. They also depicted the bravery towards their fears. This was extremely showed the great behavior in facing life trials.

Based on the analysis of each quotation, it revealed that strong personality that reflected in tenacity, professionalism and work ethics in duty even in tough times whether it is to suffice life necessity or to obtain a certain life goals by affording the efforts by oneself could motivate someone to do more for themselves in order to develop self-adequacy even to be stronger than before.

\section{Mutual Cooperation Value}

According to Kementerian Pendidikan dan Kebudayaan, The Mutual Cooperation value reflects the act of appreciating the spirit of cooperation and shoulder to shoulder to solve common problems, establish communication and friendship, provide assistance / help to people in need, showing empathy, having a high solidarity, anti discrimination (Kemdikbud, 2017). It means that the value of Mutual cooperation reflects the attitude of helping each other based on empathy feelings in society lifes and uphold solidarity in order to create harmony. The mutual cooperation value implied in the novel A Thousand Splendid Sunby Khaled Hosseini, can be seen in the data below :

You see, I knew your mother before you were born, when she was a little girl, and I tell you that she was unhappy then. The seed for what she did was palnted long ago, I'm afraid. What I mean to say is that this was not your fault, it wasn't your fault, my girl. (Hosseini, 2009, p.43) 
The statement above shows the sense of empathy from Mullah Faizullah to Mariam through moral support to strengthen Mariam who was at the time grieving over her mother's decease. He also reminds Mariam that her mother's death is not her fault, Mullah Faizullah said that he already knew her mother from she was a child, where her mother always looked unhappy, when this was seen from her mother's death chronology, some people who do not know much about Mariam's life may assume that her mother's death is caused by her. The deep sense of loss made Mariam continue to blame herself. However, Mullah Faizullah always gave a wise word and moral support to Mariam that she can endure such temptation in life. This clearly shows that the value of mutual cooperation reflected from the figure of Mullah Faizullah can be seen from the sense of empathy that he showed for Mariam and gave the spirit to get through such trials. In addition, mutual cooperation value can also be realized by building good communication with citizens in a society. This can be seen from the figure of Fariba on the following quotation :

You're Rashed jan's new wife, arent' you?" the woman said, smiling

widely. "The one from Herat. You're so young! Mariam jan, isn't it? My

name is Fariba. I live on your street, five houses to your left, the one with the

green door. (Hosseini, 2009, p.66)

The statement above shows a figure named Fariba was trying to build a good communication with Mariam who at that time just moved to Kabul with her husband. Fariba introduces herself and welcomes Mariam in a friendly manner, as she shows her home that not far from Marim's house. Fariba's friendly attitude shows that she wants to build good relationships with citizens in his neighborhood including those who have just moved. It is cleary shows that in order to build good relationships within a society, a person must establish good communication and respect for one another, which aims to build unity among a community, the figures of Fariba also showed mutual respect when she came to pay tribute to the Afghan soldiers who died while fighting :

Mammy hoisted a photo of Ahmad and Noor high over her head. It was the one of them sitting bak-to-back under the pear tree. There were others like her, women with pictures of their Shaheed husbans, sons, brothers held high.

(Hosseini, 2009, p.152)

The quotation above shows the value of mutual cooperation that seen through the attitude of respect from Kabul citizens to members of their families who were killed in the war against the soviets. It also shows a deep sense of empathy for those who were killed in defending their country. This clearly shows that the 
people of Kabul at that time were so lost due to the wars that claimed the lives of their citizens. In the different perspective, the value of mutual cooperation seen through the mutual respect shown by Laila in the following quotation :

The girl was nodding quickly. Some of her tea spilled, but she didn't notice.

"Yes, that's the other reason I came down, to thank you for taking care of me.

(Hosseini, 2009, p.219)

In the above quotation Laila expressed her gratitude for the help given by Mariam who has guarded and cared for her and thanked her for it. This shows Mariam's empathy to Laila in the form of help. It is clear that the helpful attitude can be a support in the formation of good character in the life of society. In addition, the value of mutual cooperation is also seen through the attitude of a young man who helped Laila:

You want to come with my family," the young man said.

"I know it's zahmat for you. But you look like a decent brother, and I- "

“Don't worry, hamsira. I understand. It's no trouble. Let me go and buy your tickets."

"Thank you, brother. This is sawab, a good deed. God will remember.

(Hosseini, 2009, p.254)

The quotation above shows that mutual help is not only done for people who are known each other. A young man that asked for help by Laila willing to provide assistance, he immediately bought tickets to Laila after knowing her circumstances. This young man's attitude shows a sense of empathy to someone who desperately needs help. Usually when people metthis kind of circumstances they tend to ignore the situation of people who are facing a tough times, because they do not want to get involved in their problem. But in this case, the young man is happy to provide assistance. This is clearly shows that the attitude of helping each other can still be found anywhere. The attitude that showed from the young man can be an example in shaping someones character, on the other side, Laila also got help from an orphanage guard named Zaman who also understand her condition :

It isn't your fault. Do you hear me? Not you. It's those savages, those wahshis, who are to blame. They bring shame on me as Pashtun. They've disgraced the name of my people. And you're not alone, hamsira. We get mothers like you all the time - all the time - mothers who come here who can't feed their children because the Taliban won't let them go out and make a living. So you don't blame yourself. No one here blames you. I understand.” He leaned forward. "Hamsira. I understand.

(Hosseini, 2009, p.310-311) 
In the statement above Zaman showed his concern for the difficult times that happened to Laila and willing to accept Aziza in the orphanage. This is due to the regulations made by the Taliban groups in Kabul that make the people of Kabul difficult to obtain food or make a living, so most of the mothers in Kabul leave their children in the orphanage, because they cannot feed them anymore. Zaman that was later accustomed to this situation received well the arrival of Laila and reminded her not to blame herself for what happened to her daughter. Although Zaman is an ethnic pashtun, He does not support the rules of the Taliban. The attitude demonstrated by Zaman shows a sense of empathy to help fellow citizens living in Kabul.

Based on each data found, the value of Mutual cooperation is reflected through an attitude of helping each other that seen in the from of solidarity that based on the sense of empathy to provide assistance for those who needs.

\section{Discussion}

A Thousand Splendid Sun novel by Khaled Hosseini has the values of character education. this novel can be used as a means in improving the students comprehension about the values of character education and hopefully the students could apply these values in their daily life.

\section{Religious Value}

In recent years, it has been proven that, human need religious value as the fundamental basic of life's morals and norms, therefore human has an urge to maintain the spiritual life in order to imitate and to learn good values that being told in every scripture of all believers that live within it and use it as a life guideline of how to know God closely. Meanwhile, character education of current curriculum in Indonesia managed to apply spiritual life concretely and comprehensively in order to engage the religious value with the implementation of spiritual competency which requires student to believe and to perform it within class such as praying before the class started and teacher may motivate students using God's words or verses and etc. Therefore, character education in current curriculm could also be perceived as a medium to reach the enlightenment of human being which is in order to obtain a strong connection between human with God and evaluate life behavior as God's will upon every creatures. It definitely may lead all believers toward a gratefulness and happiness life.

In the studied novel, the religious value exists in the behavior of some of the characters in the story. One of whom is the figure of Mullah Faizullah who acts as a religious teacher. Mullah Faizullah is a figure who cares about the circumstances of the people around him, especially Mariam. Although Mariam and her mother live in remote areas he always puts himself to visit Mariam and teach the verses of the Koran to her, in this explanation "The 
Koran speaks the truth, my girl. Behind every trial and sorrow that He makes us shoulder, God has a reason", Mullah Faizullah always teaches and reminds Mariam of verses in the Koran, although when Mariam is saddened by the loss of her mother, Mullhah Faizullah visits Mariam and reminds her to keep reading the verses of the Koran so she can rise from her sadness.

In the context of character education, the religious value portrayed by author through the character of Mullah Faizullah teaches the readers, especially the students that in any situation and circumstances, a person must always remember and puts believe in God, because all that exists in this world comes only from Him.

\section{Nationalism Value}

Lately, the existences of people that stand for the country are rarely found. Since, it relatively easy to find the young generation who love the new culture from other countries rather than the cultures that the heritage of preceedaters/ancestors. This value is crucial in order to build a strong nation, as mentioned in the third point of five basic principle of Indonesia which is "the unity of Indonesia" which means a strong nation is a nation that gather the power and sources of all citizens to achieve the common goal of a country. United means stand together to pursue the essence of country devotional soul. It means live and die for the beloved country with strong integrity.

Meanwhile, the act of showing less concern and loyalty to the country reflecting the lack of strong fundamental value of nationalism. As the students that learn and grow in Indonesia, nationalism value is believed as the crucial one in order to build strong sense of unity by accepting the diversity, tolerance, and etc.

In the studied novel, the nationalism value exists in the behavior of some of the characters in the story. One of them is Hakim who acts as a school teacher. Hakim is a figure who appreciates and look after culture of his nation. Although he was dismissed as a teacher for supporting the communist regime, Hakim was not disappointed of that, he still taught history and cultural value to his daughter Laila, because Hakim believed that a country will flourish if the citizens had a good quality of education, he once stated that "We're all Afghans, and that's all that should matter", for him unity is the most important things among Afghanistan citizen, Hakim sometimes takes Laila and her friend Tarik to visit the heritage of their ancestors and invites them to learn about the richness of their nation's history.

In the context of Character education The Nationalism value conceived by the author through the character Hakim teaches the readers, especially the students that a great nation is a nation that respects its history, and always upholds unity.

3. Integrity Value

Nowdays, it has been seen that, human need integrity values as the fundamental basic of living in a society to create harmony. Therefore, institutions as the formal implementation 
of education like schools or such need to consider and evaluate the implementation of integrity values to build good character that have a strong sense of responsibility and shows a trustworthy figure for the students as well.

To realize such purpose, Literature has shown concern over this value through many works, one of the most popular works is Novel, it need to be preserved for the interest of students in reading it, not because it tells about fictions or love story, a Novel is a potrait of life that. One of recommended Novel that contained integrity values is "A Thousand Splendid Suns".

In the studied Novel, the integrity value was reflected in the behavior of every character in the story. One of them is the character Laila who plays as a wife of Tariq. Laila is a character who has an attitude of responsibility. Although she had a very difficult time in her life, when she have to face the Taliban every time she wants to visit Aziza, she always cares and guards the people around her, especially Aziza, she also had to protect Aziza from Rasheed that willing to make Aziza as a beggar "I won't let you turn my daughter into a street beggar!”. Laila always observing Aziza's development even when the Taliban take over Kabul and Aziza is forced to stay in an orphanage, Laila always tries to visit Aziza every day, sometimes Laila is attacked and beaten by Taliban members when she was out of the house alone, but Laila insists visited Aziza.

In the context of Character education the behavior which the author portrays in Laila's character, invites each reader, especially students, to show their responsible attitude toward their loved ones, and strive to carry out the responsibilities well.

4. Independent Value

Lately, it has been seen that, Independent character is an important aspect in a human life, because in certain situations a person must be able to overcome a situation or problems with his/her own efforts. Therefore, institutions as the formal implementation of education like schools or such need to consider the role of independent values in building a character that have a good work ethic, tough and brave in facing various circumstances through their own efforts.

To realize such purpose, Literature has shown concern over this value through many works, one of the most popular works is Novel, it need to be preserved for the interest of students in reading it, because a Novel is a portrait of life. One of recommended Novel that shows independent values is "A Thousand Splendid Suns".

In the studied Novel, the independent value was reflected in the behavior of every character in the story. One of them is Tariq who plays as a Husband of Laila. Tariq is a character who showing a persistent and tough attitude in his life. Although he had a very difficult time in his life, when he had struggling in finding a work during the chaos that happened in Afghanistan, tariq was often rejected by a job provider because of his imperfect 
physical condition, also Tariq was unable to compete with the young man who fighting in obtaining a job. however, it did not diminish Tariq's determination, he kept searching for information until he met a shopkeeper who offered him a job.

In the context of Character education the behavior which the author portrays in Tariq's character, invites each reader, especially students, in order to learn from a formidable tariq figure who keep trying and never giving up in living through his own effort without expecting the help of others.

5. Mutual Cooperation Value

Recently, it has been found that, human need the values of mutual cooperation as the fundamental basic of creating unity among people that live in a group of society. Therefore, institutions as the formal implementation of education like schools or such need to consider and evaluate the implementation of the mutual cooperation values to build a character that have a strong sense of empathy and create solidarity in order to realize unity among citizens for the students as well.

To make it happens, Literature has shown concern over this value through many works, one of the most popular works is Novel. Novel need to be preserved for the interest of students in reading it, not because it only tells about fictions, a Novel is a potrait of life. One of recommended Novel that contained integrity values is A Thousand Splendid Suns.

In the studied novel, Mutual Cooperation value reflect the behavior of every character in the story. One of them is the character Fariba who plays the wife of Hakim, a Mother of Ahmad, Noor, and Laila. Fariba is a friendly character in the story, She is always being kind and friendly with the the neighbors where she lives, it seen when Fariba greet Mariam for the first time "My name is Fariba. I live on your street, five houses to your left, the one with the green door". On the day of Mujahideen's victory over the soviets, Fariba throws a party at her house and invites the neighbors to celebrate the Mujahideen's victory, the celebration illustrates that Fariba is also a figure who appreciates the cooperative spirit of the Mujahideen members who has brought peace back to Kabul.

In the context of Character education the behaviors described by authors in Fariba figures invite every reader especially students so that we should always keep a good social relationships with people who live around us, and respect each other in order to live in harmony.

\section{CONCLUSION}

Based on the analysis of the novel A Thousand Splendid Sunby Khaled Hosseini it was found 5 values of character education implied in it as follows: Religious Value is the value that shown the attitude love of peace, tolerance, respect for differences of religion 
and belief. Nationalism Value showed through the appreciation of the nation's culture , preserve the nation's cultural wealth, willing to sacrifice, love the homeland, respect for cultural diversity, ethnicity, and religion. Integrity Value showed an attitude of responsibility, respect for the dignity of the individual, and able to show exemplary. Independent Value that showed a strong personality that reflected in tenacity, professionalism and work ethics in duty. and the last value provided in the novel is Mutual Cooperation Value that reflects the act of appreciating the spirit of cooperation and helping each other to solve problems, establish communication and friendship with an empathy and sense of solidarity.

The values are needed in shaping a good character that can represent the identity of the nation to realize the development and competitive country especially for students as the young generation, they need to apply those values in their life as a lifestyle. It is realized that more studies and deeper analysis for the further researches related are needed in order to enhance teacher's perspectives on character Education as emphasized in presidential regulation number 87 of 2017 on strengthening character education. There by, it is suggested that the reader especially the teachers to learn more and to conduct a research that aiming to reveal and to enrich the knowledge of applying the value of character education towards students.

The implementation of character education values that proposed in this research are as follow:

1. Religious Value

Teach the student to rely on God in every circumstance and to keep the good routine of learning the scripture or verses they believe.

2. Nationalism Value

Teach students about the importance of maintaining unity to protect the nation through the attitude love of the homeland, respecting and preserving the relics of the ancestors and willing to sacrifice for the beloved country.

3. Integrity Value

Teach students to be an honest person in exam for example and make them understand that the result they achieved by themselves is more priceless rather than result they got from cheating.

4. Independent Value

Teach the students to solve the problem by themselves, it also requires a strong pedagogical approach from teacher in order to guide them properly.

5. Mutual Cooperation Value

Teach and guide the students to understand how a group of study supposed to be run. maximize each role in group discussion so that everyone works together to achieve the objective competencies, it also encourages the students to participate more in a 
team to engage with a friendship environment and advise more about how to help each other.

\section{Reference}

Azaria, S. (2008), Pedoman Tata Tulis Tugas Akhir Mahasiswa Universitas Kristen Petra. Surabaya, Indonesia.

Brown. (1973), Media Pembelajaran (Translate). Retrieved from http://a2i3scoOl.blogspot. com/2008/10/mediapembelajaran.html june 20 $0^{\text {th }} 2017$ ).

Berkowitz, M. W., \& Hoppe, M. (2009). Character Education And Gifted Children. High Ability Studies, 20(2), 131-142. doi:10.1080/13598130903358493

Collie, J. and S. Slater.(1990). Literature in the Language Classroom: A Resource B o o k ofIdeas and Activities. Cambridge: CUP.

Clisett, P. (2008). "Evaluating Qualitative Research", Journal of Orthopedic Nursing, Volume12, pp.99-105.

Cloud, H. (2006). Integrity: The Courage to Meet the Demands of Reality, retrieved from : https://pengertiandefinisi.com/pengertian-integritas-menurut-pandangan-para-ahli/. May $3^{\text {rd }} 2018$

Durkheim, E. (1965). Translated From The French By Joseph Ward Swain. The Elementary Forms Of The Religious Life.

Kartono, K. (1985). Pengertian Kemandirian Menurut Para Ahli, retrieved from : http:// aroxx.blogspot.co.id/2013/09/pengertian-kemandirian-menurut-para-ahli.html. may 3 rd 2018

Hişmanoğlu M. (2005), Teaching English Through Literature, Journal of language and Linguistic Studies pp.1-2.

Hosseini, K. (2008), A Thousand Splendid Suns, Bloomsburry.

Ismawati, E. (2018). Nationalism in Indonesian Literature as Active Learning Material. International Journal of Active Learning, retrieved from : http://journal.unnes.ac.id/ nju/index.php/ijal. May $3^{\text {rd }} 2018$

Katilmis, A., Eksi, H., \& Öztürk, C. (2011). Efficiency Of Social Studies Integrated Character Education Program. Educational Sciences: Theory \& Practice, 11(2), 854-859.

Kemdikbud. (2017) . 5 Nilai Utama Karakter Prioritas PPK, retrieved from : https://www. kemdikbud.go.id/.. August $27^{\text {th }} 2017$

Liando, N. (2012). Bilingual And Regular Class Students'attitudes Towards

English. Litera, 11(2), retrieved from : https://journal.uny.ac.id/index.php/litera/article/ $\underline{\text { download/1068/940 }}$ 
Maru, Mister G. Reconciling Literary Text with Learners' Trust in EFL Class. TEFLIN Proceeding, Malang: Universitas Islam Malik Ibrahim, 2009.

Maru, M.G. "Experimenting Jeremiadic Approach as an Alternative for TEFL in Meeting the Demand of the 2013 Curriculum." Proceeding. 61th TEFLIN International Conference, Solo, Universitas Sebelas Maret. 2014, retrieved from:http://www. academia.edu/download/43139406/Full_paper_article_TEFLIN_International_ Conference_2014_Experimenting_the_jeremiadic_approach_Mister_Gidion_ Maru.pdf

Maru, Mister Gidion; Ratu, Donal Matheos; Dukut, Ekawati Marhaenny (2018). The Use of the T-Ex Approach in Indonesian EFL Essay Writing: Feedbacks and Knowledge Exploration. IJET Vol 7, No 3.25 (2018), page 386-390

U. S. Department of Education. (2006). Character education, Our Shared Responsibility. Office of Safe and DrugFree Schools .Retrieved July 24, 2016, from www. ed.gov/admins/lead/character/brochure.html. 